\title{
Antioxidant, antibacterial activity, and FICI (Fractional Inhibitory Concentration Index) of ethanolic extract of Melastoma malabathricum leaves with amoxicillin against pathogenic bacteria
}

\author{
PRATIWI APRIDAMAYANTI ${ }^{\natural}$, RAFIKA SARI, ANITA RACHMANINGTYAS, VELLA ARANTHI \\ Department of Pharmacy, Medical Faculty, Universitas Tanjungpura. Jl. Prof. Dr. H. Hadari Nawawi, Pontianak 78124, West Kalimantan, Indonesia. \\ Tel.: +62-561-765342, ”email: apridamayanti.pratiwi@ gmail.com.
}

Manuscript received: 27 May 2021. Revision accepted: 29 June 2021.

\begin{abstract}
Apridamayanti P, Sari R, Rachmaningtyas A, Aranthi V. 2021. Antioxidant, antibacterial activity, and FICI (Fractional Inhibitory Concentration Index) of ethanolic extract of Melastoma malabathricum leaves with amoxicillin against pathogenic bacteria. Nusantara Bioscience 13: 140-147. Cengkodok plants (Melastoma malabathricum L.) from the Melastomataceae tribe have properties as a fever reliever (antipyretic), pain reliever (analgesic), relieve swelling, and treat burns or bleeding wounds. This study aimed to determine the antioxidant activity, total phenol content, total flavonoids, and MIC value of ethanol extract of M. malabathricum leaves against Bacillus cereus, Bacillus subtilis, Staphylococcus aureus, Staphylococcus epidermidis, Escherichia coli, Proteus mirabilis, and Pseudomonas aeruginosa. The method used in this study was the antioxidant activity was carried out using the DPPH test, the total phenol-flavonoid content by using gallic-quercetin acid comparison and measurement with Spectrophotometry UV/Vis. Antibacterial activity was carried out by the Kirby-Bauer disc diffusion method. Antioxidant activity in this study showed $\mathrm{IC}_{50} \mathrm{value}=5.28 \mu \mathrm{g} / \mathrm{mL}$. The chemical constituent's total phenols are $36.645 \pm 5.14 \%$, and the total flavonoids are $4.163 \pm 0.2 \%$. Antibacterial activity MIC values were obtained at a concentration of $6.25 \mathrm{mg} / \mathrm{mL}$ against $B$. cereus with a diameter of $8.28 \mathrm{~mm} \pm 0.225$, against $B$. subtilis with a diameter of $8.53 \mathrm{~mm} \pm 0.275$, against $S$. aureus with a diameter of $7.23 \mathrm{~mm} \pm 0.275$, against $S$. epidermidis with a diameter of $6.18 \mathrm{~mm}$ \pm 0.104 ; MIC values obtained at a concentration of $1.56 \mathrm{mg} / \mathrm{mL}$ in $E$. coli with a diameter of inhibition zone $6.77 \pm 0.72 \mathrm{~mm}, P$. mirabilis with a diameter of inhibition zone $6.32 \pm 0.19 \mathrm{~mm}$, and $P$. aeruginosa with a diameter of inhibition zone $6.40 \pm 0.26 \mathrm{~mm}$. The characteristic of the combination of cengkodok leaf ethanol extract and Amoxicillin towards S. epidermidis and B. subtilis with FICI value is one categories additive; P. aeruginosa with FICI value is two categories indifferent; E. coli, B. cereus, S. aureus, and P. mirabilis with FICI value is 0.5 categories synergistic.
\end{abstract}

Keywords: Antioxidant activity, Minimum Inhibitory Concentration, Melastoma malabathricum, Fractional Inhibitory Concentration Index

\section{INTRODUCTION}

Melastoma malabathricum $\mathrm{L}$ is one of the plants utilized as medicine by Indonesian people, one of them is people of Dayak ethnic in Sekajang village, Sanggau Regency, West Kalimantan province as a medicine for wounds and fever reliever. Part of the cengkodok plant or M. malabathricum used is leaf, stem, seed, and root, which has the advantage of overcoming various diseases. For example, cengkodong leaf is known to have efficacy in overcoming diarrhea, dysentery, and vaginal discharge; used for women after maternity, bleeding hemorrhoid, wound healing, laxative urine, urinary problem, and toothache (Alwash et al. 2013; Hossan et al. 2010).

In the Melastoma malabathricum leaf research by Andriyawan, the secondary metabolite content has also been tested in flavonoids, saponins, tannins, and terpenoids strongly suspected of having antibacterial activity. (Andriyawan 2015). Research conducted by Faravani and Susanti et al. 2009 stated that total flavonoid in $M$. malabathricum leaf water extract has antioxidant activity. The result shows that the water extract of $M$. malabathricum leaf with the DPPH method has a value of $\mathrm{IC}_{50}$ amounted to $10.573 \pm 0.58 \mu \mathrm{mol} / \mathrm{L}$.
Infection is a disease when bacteria disrupt the network system in the body. Bacteria have different microorganism's natural habitats, such as normal flora of the skin and normal flora of the gastrointestinal tract. Infection can happen if pathogenic bacteria destroy the body by multiplying and beating the defense mechanism in the body. Management therapy for digestive tract disorders due to bacterial infection is antibiotics. One of the antibiotics often used is broad-spectrum antibiotics such as amoxicillin. However, several studies have stated that amoxicillin is resistant to some bacteria. For example, research by Nurmala et al. (2015) says that amoxicillin has $67.1 \%$ resistance to Bacillus cereus, Staphylococcus aureus, Escherichia coli, Proteus mirabilis, and Pseudomonas aeruginosa.

The immune condition system, nutrition, environmental factor, and lack of cleanliness cause infection in the skin. A diabetic ulcer is an infection of the deepest skin tissue in the foot in Diabetes Mellitus patients, with a prevalence value in Indonesia in 2013 of $2.1 \%$. That value is higher than in 2007 , which is $1.1 \%$ with the twice increase. Urinary tract infection caused by pathogenic microorganisms from the urethra to the bladder rises and multiplies and increases in number, causing ureteral and 
kidney infection (Smeltzer 2008). According to the Ministry of Health of the Republic of Indonesia, in 2014, the total number of UTI sufferers in Indonesia was 90-100 cases per 100.000 people per year, or around 180.000 new cases per year (Ministry of Health of the Republic of Indonesia 2014). Amoxicillin antibiotics have experienced a resistance of $67.6 \%$ (Nurmala 2015; Maulida 2016). Amoxicillin is a broad-spectrum antibiotic used in the treatment of infection. Also, using natural ingredients combined with synthetic antibiotics such as amoxicillin can increase the sensitivity of antibiotics that experience resistance. Based on this, alternatives are needed to overcome resistance events. An alternative way to increase the activity of amoxicillin to bacteria resistance is by combining it with $M$. malabathricum leaf ethanol extract.

This study aimed to determine the chemical constituent of secondary metabolites M. malabathricum leaves extract ethanol and antioxidant activity. In addition, antibacterial activity with minimum inhibition concentration (MIC) and Fractional Inhibition Concentration Index (FICI) characterization of $M$. malabathricum leaf extract with amoxicillin leaves against $B$. cereus, Bacillus subtilis, $S$. aureus, Staphylococcus epidermidis, E. coli, P. mirabilis, and $P$. aeruginosa. The yield value is $\mathrm{IC}_{50}$ concentration, total phenol and flavonoid content percentage, MIC concentration value, and FICI characteristics of $M$. malabathricum leaf ethanol extract with amoxicillin.

\section{MATERIALS AND METHODS}

The material used in this research is M. malabathricum leaf extract, which was determined to be obtained in Suruh Tembawang Village, Entikong Subdistrict Sanggau Regency, West Kalimantan Province. The test bacteria used in this research were isolates from diabetic ulcer patients: E. coli, P. mirabilis, P. aeruginosa, B. cereus, $B$. subtilis, $S$. aureus, and $S$. epidermidis and became a collection of pharmacy study program laboratories at the Faculty of Medicine, University of Tanjungpura, Pontianak, Indonesia. Laminar Air Flow (Minihelix II), micropipette (Rainin E1019705K), oven $\left(\right.$ Mammert $\left.^{\circledR}\right)$, Spectrophotometer UV-Vis (Shimadzu).

\section{Procedures}

\section{Extraction of Melastoma malabathricum leaf}

The making of $M$. malabathricum leaf extract was conducted with the maceration method. Macerate is then collected and concentrated with a rotary evaporator until a thick extract is obtained.

\section{Media preparation}

As much 38 gram MHA (Mueller Hinton Agar) media dissolved in sterile aquadest amounted to $1000 \mathrm{~mL}$. The solution was then heated until all dissolved. In hot conditions, that solvent was put into Erlenmeyer, and the media solvent $\mathrm{pH}$ was checked, then sterilized in an autoclave at $121^{\circ} \mathrm{C}$ for 15 minutes (Zimbro 2009).

\section{Concentration series solvent preparation}

Melastoma malabathricum leaf ethanol extract consists of making $10 \%$ stock solvent and concentration series solvent. M. malabathricum leaf ethanol extract $100 \mathrm{mg} / \mathrm{mL}$ stock solvent is made by dissolving $10 \mathrm{~g}$ extract in $100 \mathrm{~mL}$ DMSO. Concentration extract of M. malabathricum leaf is made in several series of concentrations which are 12.5 $\mathrm{mg} / \mathrm{mL}, 6.25 \mathrm{mg} / \mathrm{mL}, 3.12 \mathrm{mg} / \mathrm{mL}, 1.56 \mathrm{mg} / \mathrm{mL}, 0.78$ $\mathrm{mg} / \mathrm{mL}, 0.39 \mathrm{mg} / \mathrm{mL}$, and $0.19 \mathrm{mg} / \mathrm{mL}$ towards bacteria $E$. coli, $P$. mirabilis, $P$. aeruginosa. The concentration extract used in this study are $25 \mathrm{mg} / \mathrm{mL} ; 12,5 \mathrm{mg} / \mathrm{mL} ; 6,25$ $\mathrm{mg} / \mathrm{mL} ; 3,12 \mathrm{mg} / \mathrm{mL} ; 1,56 \mathrm{mg} / \mathrm{mL} ; 0.78 \mathrm{mg} / \mathrm{mL}$, and 0.39 $\mathrm{mg} / \mathrm{mL}$ for bacteria $B$. cereus, B. subtilis, S. aureus, and $S$. epidermidis.

\section{Bacterial inoculum preparation}

Bacterial colonies of E. coli, P. mirabilis, $P$. aeruginosa, B. cereus, B. subtilis, $S$. aureus, and $S$. epidermidis are taken by work culture using a sterile ose needle. It was suspended into $10 \mathrm{~mL}$ sterile $\mathrm{NaCl} 0.9 \%$ solvent until turbidity was obtained, then incubated at $37^{\circ} \mathrm{C}$. The turbidity obtained is then compared to the $\mathrm{Mc}$ standard. Farland 0.5 is equivalent to 1 x 108 bacterial cells $/ \mathrm{mL}$, and after the equivalent, this suspension is used as a test bacterium (ICMR 2009).

\section{Thin Layer Chromatography}

Identification with Thin Layer Chromatography (TLC) using silica gel F254 plate. The mobile phase for flavonoid and phenol compounds is n-butanol: acetic acid: water (4:1:5). The mobile phase used for terpenoid compounds is n-hexane: ethyl acetate (8:2). Spots on TLC were observed in ultraviolet with $254 \mathrm{~nm}$ and ultraviolet with $366 \mathrm{~nm}$. Spotting viewers for flavonoids is $\mathrm{AlCl}_{3}$, spotting views for phenols, namely $\mathrm{FeCl}_{3}$, and spotting views for terpenoids, namely vanillin-sulfuric acid reagents.

\section{Total phenol and flavonoid contents}

Determination of chemical constituent total phenolic with Follin Ciocalteau method. As much as $10 \mathrm{mg}$ ethanol extract of M. malabathricum, Leaves dissolved to $10 \mathrm{ml}$ with methanol as stock solution. The test solution was made with a $150 \mu \mathrm{g} / \mathrm{mL}$ concentration and reacted with 500 $\mu 1$ Follin Ciocalteau and $2 \mathrm{ml} \mathrm{Na} \mathrm{CO}_{3} 10 \%$. Then heated at the temperature of $50^{\circ} \mathrm{C}$ for 5 minutes and incubated for 10 minutes. Measurement absorbance in wavelength $757 \mathrm{~nm}$ and expressed as gallic acid equivalent $(\%)$.

The total flavonoid content study using the Chang method. M. malabathricum. ethanol leaf extract is added with 0.1 $\mathrm{ml} \mathrm{AlCl}_{3} 10 \%, 0.1 \mathrm{ml} \mathrm{CH} \mathrm{CHOONa}_{3} \mathrm{M}$. The solvent mixture was incubated for 30 minutes. Measured absorption at a wavelength of $425 \mathrm{~nm}$, the total flavonoid content using quercetin as a comparison standard and expressed as quercetin equivalent (\%) (Hanani. 2014).

\section{Antioxidant activity test}

A total of $25 \mathrm{mg}$ of $M$. malabathricum leaves extract dissolved in $25 \mathrm{~mL}$ of methanol p.a made as a stock solution was conducted preliminary tests of antioxidant using TLC plates (Thin Layer Chromatography) with a 
mobile phase of butanol: acetic acid: water (4: 1: 5). Elution results are then sprayed with a DPPH solution concentration is $1000 \mu \mathrm{g} / \mathrm{mL}$. A test antioxidant followed this with a spectrophotometer. The concentration leaf ethanol extract of M. malabathricum is $1,4,7,10$ dan 13 $\mu \mathrm{g} / \mathrm{mL}$ as much $1 \mathrm{ml}$ and $3 \mathrm{ml}$ DPPH solution with a concentration of $20 \mu \mathrm{g} / \mathrm{mL}$ were incubated for 30 minutes. Measurement using a UV-VIS spectrophotometer at a wavelength of $515.1 \mathrm{~nm}$.

\section{Determination of MIC Value}

Determination of antibacterial activity by using disc diffusion Kirby-Bauer method. Bacteria suspension in inoculation using a sterile cotton bud on the surface of media MHA. The $6 \mathrm{~mm}$ disc paper that has been soaked in each concentration of the M. malabathricum leaf ethanol extract with concentrations $12.5 \mathrm{mg} / \mathrm{mL}, 6.25 \mathrm{mg} / \mathrm{mL}, 3.12$ $\mathrm{mg} / \mathrm{mL}, 1.56 \mathrm{mg} / \mathrm{mL}, 0.78 \mathrm{mg} / \mathrm{mL}, 0.39 \mathrm{mg} / \mathrm{mL}$ and 0.19 $\mathrm{mg} / \mathrm{mL}$ towards bacteria $E$. coli, $P$. mirabilis, $P$. aeruginosa. The concentration extracts used in this study are $25 \mathrm{mg} / \mathrm{mL} ; 12,5 \mathrm{mg} / \mathrm{mL} ; 6,25 \mathrm{mg} / \mathrm{mL} ; 3,12 \mathrm{mg} / \mathrm{mL}$; $1,56 \mathrm{mg} / \mathrm{mL} ; 0.78 \mathrm{mg} / \mathrm{mL}$, and $0.39 \mathrm{mg} / \mathrm{mL}$ for bacteria $B$. cereus, B. subtilis, S. aureus, and $S$. epidermidis put in the surface of media MHA. Media MHA is incubated in an incubator at $37^{\circ} \mathrm{C}$ for 24 hours after the diameter of the growth of the resistance area (clear zone) around the paper disc using calipers (ICMR 2009).

\section{Determination of FICI Value}

Antibacterial activity combination with extract tests was conducted using the Kirby-Bauer disc diffusion method. The MIC concentration from M. malabathricum leaf ethanol extract combined with MIC concentration from amoxicillin with the volume ratio of $1: 1$. The integrated solution of M. malabathricum leaves ethanol extract and amoxicillin using the Kirby-Bauer disk diffusion method. Testing a combination solution against bacteria which are E. coli, P. mirabilis, P. aeruginosa, S. epidermidis, $B$. cereus, S. aureus, and B. subtilis using four variations of concentration which are two times, one time, half times and quarter times from single antibiotic MIC which are Amoxicillin and MIC ethanol extracts of single $M$. malabathricum leaves (Tinrat. 2015).

\section{Data analysis}

Antioxidant test result based on IC50 value $(\mu \mathrm{g} / \mathrm{mL})$, phenol, and flavonoid total with equivalence with gallic acid and quercetin in percent, MIC value $(\mu \mathrm{g} / \mathrm{mL})$ in each bacteria. Data is presented in average value and standard deviation. Characterization of FICI is determined based on the FICI table.

\section{RESULTS AND DISCUSSION}

\section{Determination of phytochemical and antioxidant activity}

Melastoma malabathricum ethanol extract has flavonoids, phenol, tannins, saponins, and terpenoid compounds. The ethanol extract of $M$. malabathricum leaves is proven to have metabolite compounds in flavonoid, phenol, and terpenoid, as shown in Table 1 and Figure 1.

Table 1. Thin Layer Chromatography Result of Melastoma malabathricum Leaf Ethanol Extracts Total Phenol Content, Total Flavonoid Content, and Antioxidant Activity.

\begin{tabular}{llll}
\hline Compound & Mobile Phase & $\begin{array}{l}\text { Spotting } \\
\text { Viewer }\end{array}$ & Result \\
\hline Flavonoid & $\begin{array}{l}\text { Butanol: acetic } \\
\text { acid: water } \\
(4: 1: 5)\end{array}$ & $\mathrm{AlCl}_{3}$ & $\begin{array}{l}\text { Yellow } \\
\text { patches }\end{array}$ \\
Phenol & $\begin{array}{l}\text { Butanol: acetic } \\
\text { acid: water } \\
(4: 1: 5)\end{array}$ & $\mathrm{FeCl}_{3}$ & Black patches \\
Terpenoid & $\begin{array}{l}\text { N-hexane: ethyl } \\
\text { acetate } \\
(8: 2)\end{array}$ & $\begin{array}{l}\text { Vanillin- } \\
\text { sulfuric acid }\end{array}$ & Blue patches \\
\hline
\end{tabular}

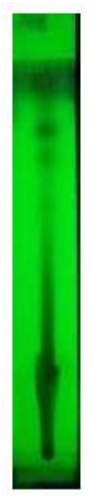

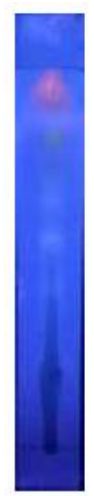

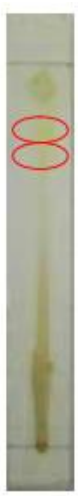

Chromatogram Pattern of Flavonoid Compound UV $254 \mathrm{~nm}$ UV $366 \mathrm{~nm}$ AlC13 Spotting Viewer

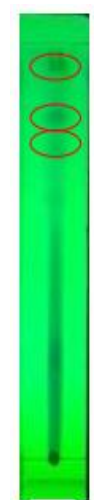

a b

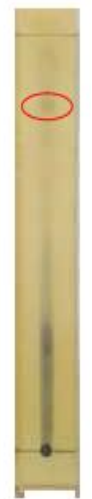

Chromatogram Pattern of Fenol Compound UV $254 \mathrm{~nm}$ UV $366 \mathrm{~nm}$ $\mathrm{FeCl} 3$ Spotting Viewer

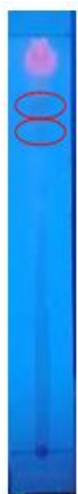

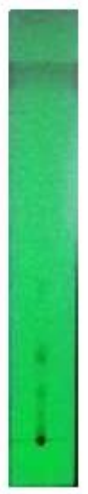

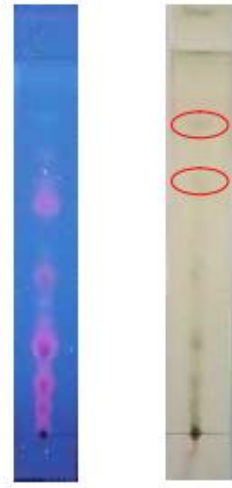

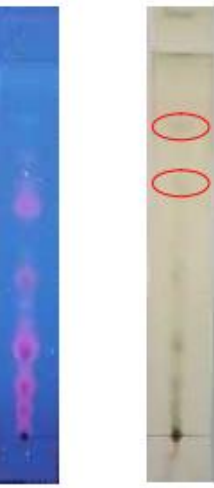

b

c

Chromatogram Pattern of Terpenoid Compound UV $254 \mathrm{~nm}$ UV $366 \mathrm{~nm}$ Vanillin-Sulfuric Acid Spotting Viewer

Figure 1. Chromatogram pattern of flavonoid, phenol, and terpenoid compounds of Melastoma malabathricum leaf ethanol extract 
The total phenol and flavonoid content of ethanol extract of $M$. malabathricum leaves using gallic acid and quercetin as a standard. The linear regression equation of the gallic acid compound was $\mathrm{y}=0.012 \mathrm{x}+0.001$, and the quercetin was $\mathrm{y}=0.035 \mathrm{x}-0.019$ results obtained can be seen in Table 2. Preliminary testing of antioxidant activity using silica gel chromatography plates obtained patches of compounds that turn yellow after spraying with DPPH. The test result can be seen in Figure 2. Antioxidant activity is conducted by using DPPH compounds as free radical compounds using a spectrophotometer in wavelength 515,1 $\mathrm{nm}$ obtained concentration of $\mathrm{IC}_{50}$ amounted to $5.28 \pm$ $0.007 \mathrm{ppm}$

\section{Determination of Melastoma malabathricum leaf ethanol extract MIC}

The determination of M. malabathricum leaves ethanol extract MIC value towards bacteria $E$. coli, $P$. mirabilis, $P$. aeruginosa, B. cereus, B. subtilis, $S$. aureus, and $S$. epidermidis using disc diffusion Kirby-Bauer method with the former resistance zone. The result of the antibacterial activities can be seen in Figures 3 and 4 and Table 5 . Antibacterial test results formed clear zone diameter and MIC value according to Tables 3 and 4. From the data MIC (Minimum Inhibitory Concentration) value of $M$. malabathricum leaf extract towards E. coli, P. mirabilis, and $P$. aeruginosa bacteria shown in the concentration of $1.56 \mathrm{mg} / \mathrm{mL}$ with an average of resistance zone sustainably amounted to $6.77 \pm 0.72 \mathrm{~mm}, 6.32 \pm 0.19 \mathrm{~mm}$, dan $6.40 \pm$ $0.26 \mathrm{~mm}$. The concentration used are $25 \mathrm{mg} / \mathrm{mL} ; 12.5$ $\mathrm{mg} / \mathrm{mL} ; 6.25 \mathrm{mg} / \mathrm{mL} ; 3.12 \mathrm{mg} / \mathrm{mL} ; 1.56 \mathrm{mg} / \mathrm{mL} ; 0.78$ $\mathrm{mg} / \mathrm{mL}$, and $0.39 \mathrm{mg} / \mathrm{mL}$ for bacteria $B$. cereus, B. subtilis, $S$. aureus, and $S$. epidermidis is obtained concentration of $6.25 \mathrm{mg} / \mathrm{mL}$ M. malabathricum leaf ethanol extract with resistance zone value with a diameter of $8.28 \mathrm{~mm} \pm 0.225$, $8.53 \mathrm{~mm} \pm 0.275,7.23 \mathrm{~mm} \pm 0.275$, and $6.18 \mathrm{~mm} \pm 0.104$.

\section{Determination of FICI value of Melastoma malabathricum Leaf Ethanol Extract with Amoxicillin}

The antibacterial characteristics FICI value of the combination was calculated by summing the Fractional Inhibitory Concentration of the antibiotic or FIC (A) and the Fractional Inhibitory Concentration of the test material or FIC (B). So that the FICI value is obtained, the combination's characteristics can be seen based on this value (Table 6). The concentration included in the calculation is the most negligible combination concentration that produces the inhibition zone.

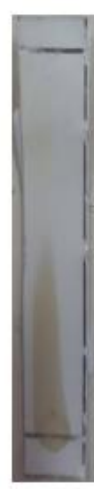

A

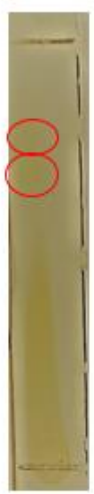

B
Figure 2. Preliminary antioxidant activity test: A) Before sprayed by DPPH, B) After Sprayed by DPPH

Table 2. Total phenol content, total flavonoids, and antioxidant activity of Melastoma malabathricum leaf ethanol extract

\begin{tabular}{lccc}
\hline & $\begin{array}{c}\text { Phenol } \\
\text { level (\%) }\end{array}$ & $\begin{array}{c}\text { Flavonoid } \\
\text { level (\%) }\end{array}$ & $\begin{array}{c}\text { Antioxidant } \\
\text { activity (ppm) }\end{array}$ \\
\hline $\begin{array}{l}\text { Ethanol extract } M . \\
\text { malabathricum leaf }\end{array}$ & $36.645 \pm 5.14$ & $4.163 \pm 0.242$ & $5.28 \pm 0.007$ \\
\hline
\end{tabular}

Table 4. Result of Melastoma malabathricum leaf ethanol extract MIC

\begin{tabular}{llll}
\hline & \multicolumn{3}{c}{$\begin{array}{c}\text { Average of inhibition zone diameter } \\
\text { Concentration }\end{array}$} \\
\cline { 2 - 4 } & $\begin{array}{c}\text { Escherichia } \\
\text { coli }\end{array}$ & $\begin{array}{c}\text { Proteus } \\
\text { mirabilis }\end{array}$ & $\begin{array}{c}\text { Pseudomonas } \\
\text { aeruginosa }\end{array}$ \\
\hline Extract $12.5 \mathrm{mg} / \mathrm{mL}$ & $10.77 \pm 0.45$ & $10.67 \pm 0.35$ & $10.40 \pm 0.36$ \\
Extract $6.25 \mathrm{mg} / \mathrm{mL}$ & $9.35 \pm 0.43$ & $9.37 \pm 0.40$ & $8.98 \pm 0.64$ \\
Extract $3.12 \mathrm{mg} / \mathrm{mL}$ & $7.78 \pm 0.58$ & $8.62 \pm 0.08$ & $7.83 \pm 0.57$ \\
Extract $1.56 \mathrm{mg} / \mathrm{mL}$ & $6.77 \pm 0.72$ & $6.32 \pm 0.19$ & $6.40 \pm 0.26$ \\
Extract $0.78 \mathrm{mg} / \mathrm{mL}$ & - & - & - \\
Extract $0.39 \mathrm{mg} / \mathrm{mL}$ & - & - & - \\
Extract $0.19 \mathrm{mg} / \mathrm{mL}$ & - & - & - \\
\hline
\end{tabular}

Table 3. Result of Melastoma malabathricum leaf ethanol extract MIC

\begin{tabular}{lllll}
\hline \multirow{2}{*}{ Concentration } & \multicolumn{3}{c}{ Diameter of Inhibition Zone (mm) } \\
\cline { 2 - 5 } & \multicolumn{1}{c}{ Bacillus cereus } & Bacillus subtilis & Staphylococcus aureus & $\begin{array}{c}\text { Staphylococcus } \\
\text { epidermidis }\end{array}$ \\
\hline $25 \mathrm{mg} / \mathrm{mL}$ & $10.35 \pm 0.377$ & $11.08 \pm 0.104$ & $10.77 \pm 0.236$ & $7.73 \pm 0.283$ \\
$12.5 \mathrm{mg} / \mathrm{mL}$ & $9.42 \pm 0.321$ & $9.13 \pm 0.104$ & $9.28 \pm 0.321$ & $6.82 \pm 0.161$ \\
$6.25 \mathrm{mg} / \mathrm{mL}$ & $8.28 \pm 0.225$ & $8.53 \pm 0.275$ & $7.23 \pm 0.275$ & $6.18 \pm 0.104$ \\
$3.12 \mathrm{mg} / \mathrm{mL}$ & - & - & - & - \\
$1.56 \mathrm{mg} / \mathrm{mL}$ & - & - & - & - \\
$0.78 \mathrm{mg} / \mathrm{mL}$ & - & - & - & - \\
$0.39 \mathrm{mg} / \mathrm{mL}$ & - & - & - & - \\
\hline
\end{tabular}


Table 5. Inhibition zone diameter of ethanol extract of Melastoma malabathricum leaf combination with Amoxicillin towards Staphylococcus epidermidis. Bacillus subtilis, and Pseudomonas aeruginosa

\begin{tabular}{|c|c|c|}
\hline Concentration $(\mathrm{mg} / \mathrm{mL})$ & & $\overline{\mathbf{x}}(\mathbf{m m})^{*}$ \\
\hline Amoxicillin & Extract & S. epidermidis \\
\hline $0015625^{\mathrm{W}}$ & $125^{\mathrm{W}}$ & 81 \\
\hline $00078125^{\mathrm{x}}$ & $625^{\mathrm{x}}$ & 74 \\
\hline $0003906^{\mathrm{Y}}$ & $3125^{\mathrm{Y}}$ & 66 \\
\hline $0001953^{Z}$ & $1562^{Z}$ & - \\
\hline Amoxicillin & Extract & B. subtilis \\
\hline $0003906^{\mathrm{W}}$ & $125^{\mathrm{W}}$ & 885 \\
\hline $0001953^{\mathrm{X}}$ & $625^{\mathrm{x}}$ & 745 \\
\hline $0000976^{Y}$ & $3125^{\mathrm{Y}}$ & 68 \\
\hline $0000488^{Z}$ & $1562^{Z}$ & - \\
\hline Amoxicillin & Extract & P. aeruginosa \\
\hline $0125^{\mathrm{W}}$ & $312^{\mathrm{W}}$ & 9 \\
\hline $00625^{\mathrm{x}}$ & $156^{\mathrm{X}}$ & 84 \\
\hline $003125^{Y}$ & $078^{\mathrm{Y}}$ & - \\
\hline $0015625^{Z}$ & $039^{\mathrm{Z}}$ & - \\
\hline Amoxicillin & Extract & Escherichia coli \\
\hline $00312^{\mathrm{W}}$ & $312^{\mathrm{W}}$ & 76 \\
\hline $00156^{\mathrm{X}}$ & $156^{\mathrm{X}}$ & 66 \\
\hline $00078^{\mathrm{Y}}$ & $078^{\mathrm{Y}}$ & 65 \\
\hline $00039^{\mathrm{Z}}$ & $039^{\mathrm{Z}}$ & 635 \\
\hline Amoxicillin & Extract & Proteus mirabilis \\
\hline $00078^{\mathrm{W}}$ & $312^{\mathrm{W}}$ & 64 \\
\hline $00039^{\mathrm{X}}$ & $156^{\mathrm{X}}$ & 62 \\
\hline $00019^{Y}$ & $078^{\mathrm{Y}}$ & 619 \\
\hline $00009^{\mathrm{Z}}$ & $039^{Z}$ & 608 \\
\hline Amoxicillin & Extract & Bacillus cereus \\
\hline $1^{\mathrm{W}}$ & 125 & 127 \\
\hline $05^{\mathrm{x}}$ & 625 & 675 \\
\hline $025^{\mathrm{Y}}$ & 3125 & 63 \\
\hline $0125^{\mathrm{Z}}$ & 1562 & 615 \\
\hline Amoxicillin & Extract & Staphylococcus aureus \\
\hline $0125^{\mathrm{W}}$ & $125^{\mathrm{W}}$ & 755 \\
\hline $00625^{\mathrm{x}}$ & $625^{\mathrm{X}}$ & 66 \\
\hline $00312^{\mathrm{Y}}$ & $3125^{\mathrm{Y}}$ & 65 \\
\hline $00156^{\mathrm{Z}}$ & $1562^{\mathrm{Z}}$ & 62 \\
\hline
\end{tabular}

Note: Description: $\mathrm{x}=$ average, ${ }^{\mathrm{W}}=2$ times concentration of MIC,

$\mathrm{X}=1$ time concentration of MIC, ${ }^{\mathrm{Y}}=1 / 2$ time concentration of MIC, ${ }^{\mathrm{Z}}=1 / 4$ time concentration of MIC, $*=$ Test was conducted in 3 times of replications

\section{Discussion}

Melastoma malabathricum ethanol extract has flavonoids, phenol, tannins, saponins, and terpenoid compounds. Meutia (2017) researches the phytochemicals screening of $M$. malabathricum leaf ethanol extract compounds: flavonoids, tannin, polyphenol, saponin, and triterpenoid (Meutia 2017).

The determination of the MIC (Minimum Inhibitory Concentration) value aims to find the lowest concentration of M. malabathricum leaves ethanol extract to show antibacterial activity marked with a clear zone. The diameter of the resistance zone formed becomes smaller with the decrease in concentration. Therefore, it can be assumed that there is an equal relationship between the reduction of extract concentration and the smaller resistance zone formed. This study is related to compound concentration which is dissolved in the extract. Concentration affects the diffusion speed of nutritious substances. The bigger the concentration of the extract, the faster the diffusion results, and the greater the antibacterial power and the wider diameter of the inhibitory zone formed (Putri 2017). The difference in inhibition is caused by differences in organism sensitivity, mechanism, and work synergy between the active compounds in the extract (Haryati 2015).

Melastoma malabathricum leaf ethanol extract MIC towards bacteria $E$. coli is $1.56 \mathrm{mg} / \mathrm{mL}$. According to Purwanto's (2015) research, this result stated that methanol fraction of $M$. malabathricum leaf has MIC value amounted to $1 \mathrm{mg} / \mathrm{mL}$ towards bacteria E. coli (Purwanto 2015). MIC value of $M$. malabathricum leaf ethanol extract towards bacteria $P$. mirabilis is $1.56 \mathrm{mg} / \mathrm{mL}$. This result differs from research by Omar et al. (2012), which stated that the MIC value in Melastoma malabathricum L. flower extract is $50 \mathrm{mg} / \mathrm{mL}$ (Omar et al. 2012). The different concentrations can be caused by the other part of the plants used. MIC value of $M$. malabathricum leaf ethanol extract for $P$. aeruginosa amounts to $1.56 \mathrm{mg} / \mathrm{mL}$. According to research conducted by Alwash et al. (2013), this result stated that $M$. malabathricum leaf methanol extract has MIC value amounted to $1.56 \mathrm{mg} / \mathrm{mL}$ for bacteria $P$. aeruginosa (Alwash et al. 2013).

Table 6. Result of determination of FICI value combination of Melastoma malabathricum leaf ethanol extract with antibiotics towards bacterial test

\begin{tabular}{|c|c|c|c|c|c|c|}
\hline \multirow[t]{2}{*}{ Bacterial test } & \multicolumn{2}{|c|}{$\begin{array}{c}\text { Concentration in combination } \\
(\mathrm{mg} / \mathrm{mL})\end{array}$} & \multirow[t]{2}{*}{ FIC(A) } & \multirow[t]{2}{*}{ FIC (B) } & \multirow[t]{2}{*}{ FICI } & \multirow[t]{2}{*}{ Characteristics } \\
\hline & Amoxicillin & Extract & & & & \\
\hline Staphylococcus epidermidis & 0.003906 & 3.125 & 0.5 & 0.5 & 1 & Additive \\
\hline Bacillus subtilis & 0.0009765 & 3.125 & 0.5 & 0.5 & 1 & Additive \\
\hline Pseudomonas aeruginosa & 0.0625 & 1.56 & 1 & 1 & 2 & Indifferent \\
\hline Escherichia coli & 0.0039 & 0.39 & 0.25 & 0.25 & 0.5 & Synergistics \\
\hline Proteus mirabilis & 0.0009 & 0.39 & 0.25 & 0.25 & 0.5 & Synergistics \\
\hline Bacillus cereus & 0.125 & 1.562 & 0.25 & 0.25 & 0.5 & Synergistics \\
\hline Staphylococcus aureus & 0.0312 & 3.125 & 0.25 & 0.25 & 0.5 & Synergistics \\
\hline
\end{tabular}

Description: FIC(A) = Inhibitory concentration of amoxicillin fraction, FIC(B) = Inhibitory concentration of caras leaf ethanol extract, FICI = Fractional Inhibitory Concentration Index 
Bacteria E. coli, P. mirabilis, and P. aeruginosa are Negative Gram bacteria. The component of cell wall Negative Gram bacteria is lipids, peptidoglycan, and an outer membrane consisting of phospholipids (inner layer) and lipopolysaccharides (outer layer) so that they are nonpolar (Haryati 2015). B. cereus, B. subtilis, S. aureus, and $S$. epidermidis are included in positive Gram bacteria. The characteristics of positive Gram bacteria have cell walls with a thickness of 20-50 nm surrounded by cytoplasm membranes. The cell wall component in Positive Gram bacteria consists of peptidoglycan, which forms a thick and stiff wall, theatrics acid, and theicuronic acid.

In this study, a combination of $M$. malabathricum leaf ethanol extract and amoxicillin to test bacteria have different characteristics. These can be affected based on the type of bacteria Gram which is positive Gram and negative Gram. The difference between those Grams is in the former of the bacteria cell wall. Positive Gram bacteria have thick peptidoglycan in the bacteria cell wall. In contrast, negative Gram bacteria have lipoprotein in the outer part, thin peptidoglycan in the middle layer, and lipopolysaccharides in the inner layer (Pelczar 2008; Radji 2010). Therefore, amoxicillin's mechanism as an antibacterial prevents the biosynthesis of cell wall mucopeptide. That is considered the cause why amoxicillin is more effective towards positive Gram bacteria than negative Gram bacteria (Kaur et al. 2011).

Melastoma malabathricum leaf ethanol extract's ability to prevent the growth of bacteria is caused by the existence of compounds that have a role as antibacterial, flavonoid, phenol, and terpenoid. Based on Meutia's (2017) research, the phytochemicals screening result in ethanol extract of $M$. malabathricum leaves have secondary metabolite compounds: flavonoid, tannin polyphenol, saponin, and triterpenoid (Meutia 2017).

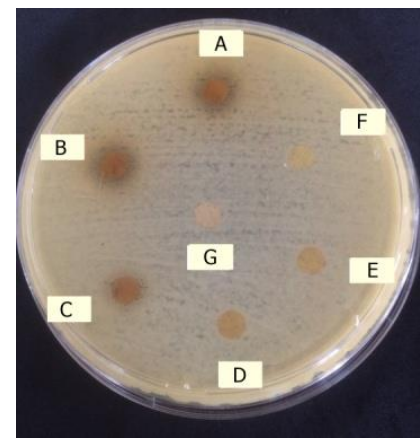

Bacillus cereus $\mathrm{A}=25 \mathrm{mg} / \mathrm{mL}$ $\mathrm{B}=12.5 \mathrm{mg} / \mathrm{mL}$ $\mathrm{C}=6.25 \mathrm{mg} / \mathrm{mL}$ $\mathrm{D}=3.12 \mathrm{mg} / \mathrm{mL}$ $\mathrm{E}=1.56 \mathrm{mg} / \mathrm{mL}$ $\mathrm{F}=0.78 \mathrm{mg} / \mathrm{mL}$ $\mathrm{G}=0.39 \mathrm{mg} / \mathrm{mL}$

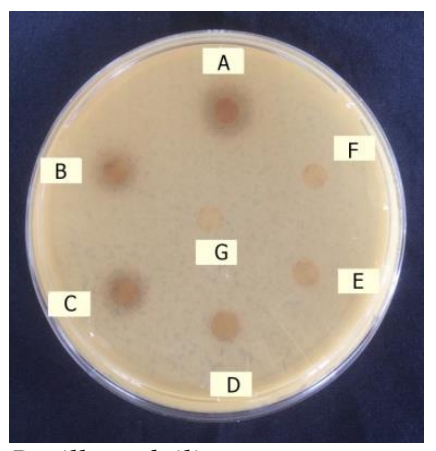

Bacillus subtilis

$\mathrm{A}=25 \mathrm{mg} / \mathrm{mL}$

$\mathrm{B}=12.5 \mathrm{mg} / \mathrm{mL}$

$\mathrm{C}=6.25 \mathrm{mg} / \mathrm{mL}$

$\mathrm{D}=3.12 \mathrm{mg} / \mathrm{mL}$

$\mathrm{E}=1.56 \mathrm{mg} / \mathrm{mL}$

$\mathrm{F}=0.78 \mathrm{mg} / \mathrm{mL}$

$\mathrm{G}=0.39 \mathrm{mg} / \mathrm{mL}$

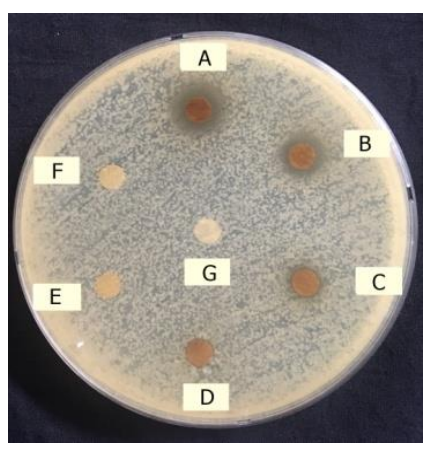

Staphylococcus aureus

$\mathrm{A}=25 \mathrm{mg} / \mathrm{mL}$

$\mathrm{B}=12.5 \mathrm{mg} / \mathrm{mL}$

$\mathrm{C}=6.25 \mathrm{mg} / \mathrm{mL}$

$\mathrm{D}=3.12 \mathrm{mg} / \mathrm{mL}$

$\mathrm{E}=1.56 \mathrm{mg} / \mathrm{mL}$

$\mathrm{F}=0.78 \mathrm{mg} / \mathrm{mL}$

$\mathrm{G}=0.39 \mathrm{mg} / \mathrm{mL}$

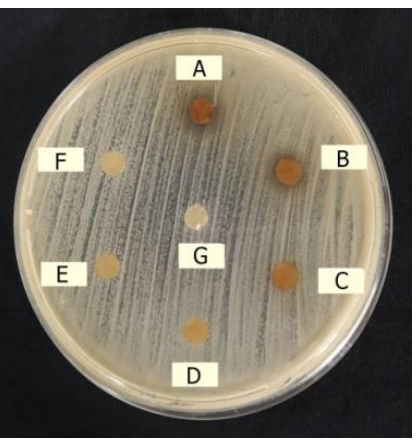

Staphylococcus epidermidis

$\mathrm{A}=25 \mathrm{mg} / \mathrm{mL}$

$\mathrm{B}=12.5 \mathrm{mg} / \mathrm{mL}$

$\mathrm{C}=6.25 \mathrm{mg} / \mathrm{mL}$

$\mathrm{D}=3.12 \mathrm{mg} / \mathrm{mL}$

$\mathrm{E}=1.56 \mathrm{mg} / \mathrm{mL}$

$\mathrm{F}=0.78 \mathrm{mg} / \mathrm{mL}$

$\mathrm{G}=0.39 \mathrm{mg} / \mathrm{mL}$

Figure 3. Antibacterial activity test of Melastoma malabathricum leaf ethanol extract

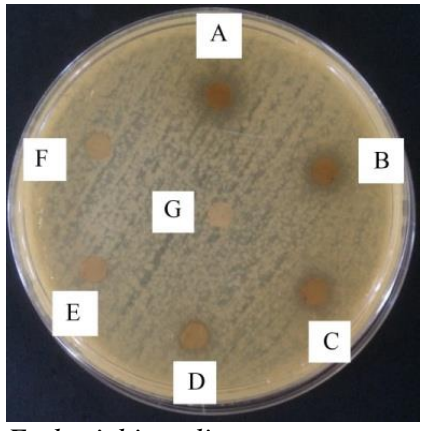

Escherichia coli

$\mathrm{A}=12.5 \mathrm{mg} / \mathrm{mL}$

$\mathrm{B}=6.25 \mathrm{mg} / \mathrm{mL}$

$\mathrm{C}=3.12 \mathrm{mg} / \mathrm{mL}$

$\mathrm{D}=1.56 \mathrm{mg} / \mathrm{mL}$

$\mathrm{E}=0.78 \mathrm{mg} / \mathrm{mL}$

$\mathrm{F}=0.39 \mathrm{mg} / \mathrm{mL}$

$\mathrm{G}=0.19 \mathrm{mg} / \mathrm{mL}$

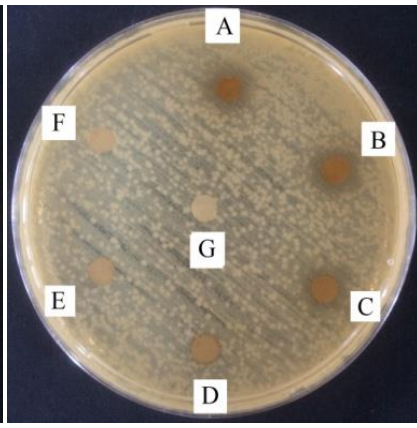

Proteus mirabilis

$\mathrm{A}=12.5 \mathrm{mg} / \mathrm{mL}$

$\mathrm{B}=6.25 \mathrm{mg} / \mathrm{mL}$

$\mathrm{C}=3.12 \mathrm{mg} / \mathrm{mL}$

$\mathrm{D}=1.56 \mathrm{mg} / \mathrm{mL}$

$\mathrm{E}=0.78 \mathrm{mg} / \mathrm{mL}$

$\mathrm{F}=0.39 \mathrm{mg} / \mathrm{mL}$

$\mathrm{G}=0.19 \mathrm{mg} / \mathrm{mL}$

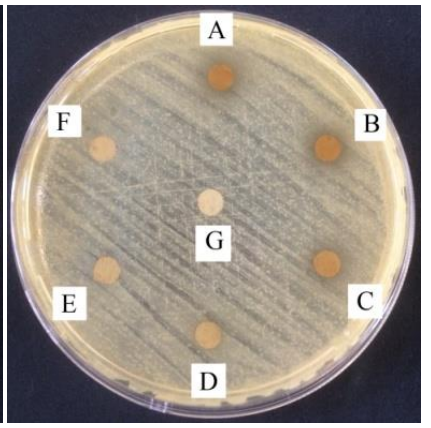

Pseudomonas aeruginosa

$\mathrm{A}=12.5 \mathrm{mg} / \mathrm{mL}$

$\mathrm{B}=6.25 \mathrm{mg} / \mathrm{mL}$

$\mathrm{C}=3.12 \mathrm{mg} / \mathrm{mL}$

$\mathrm{D}=1.56 \mathrm{mg} / \mathrm{mL}$

$\mathrm{E}=0.78 \mathrm{mg} / \mathrm{mL}$

$\mathrm{F}=0.39 \mathrm{mg} / \mathrm{mL}$

$\mathrm{G}=0.19 \mathrm{mg} / \mathrm{mL}$

Figure 4. Antibacterial activity test of Melastoma malabathricum leaf ethanol extract 


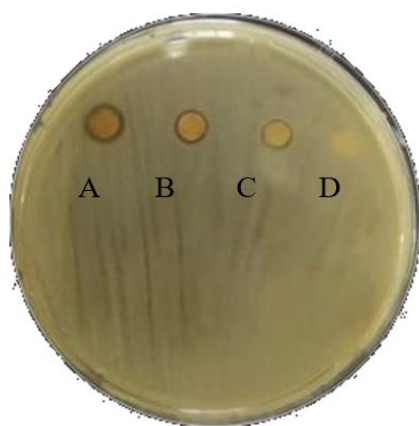

Staphylococcus epidermidis

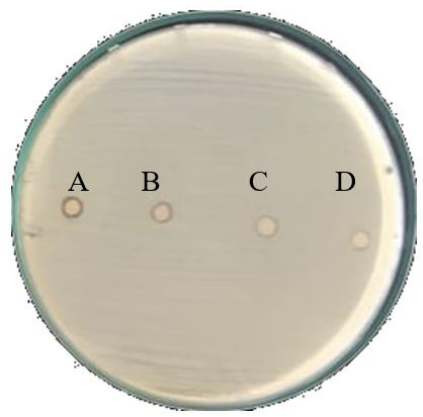

Proteus mirabilis

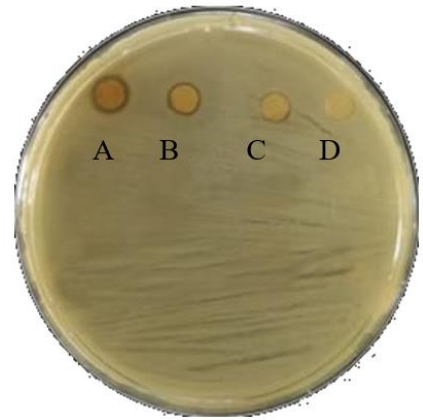

Bacillus subtilis

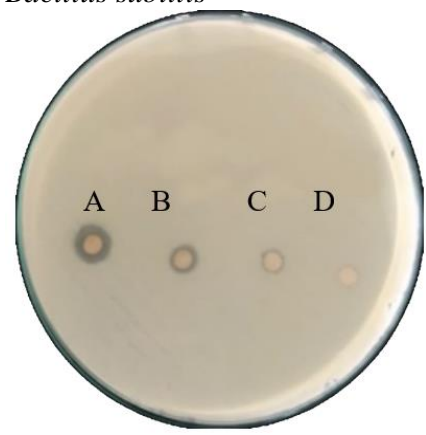

Bacillus cereus

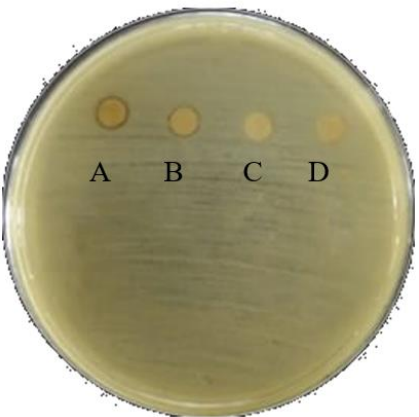

Pseudomonas aeruginosa

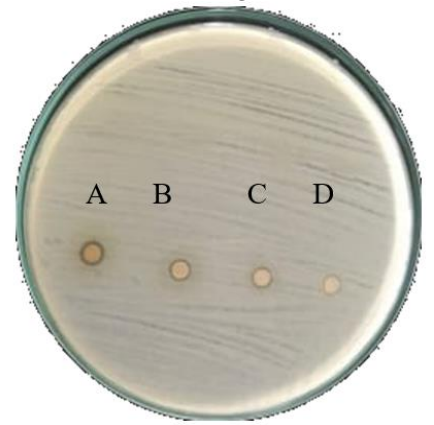

Staphylococcus aureus

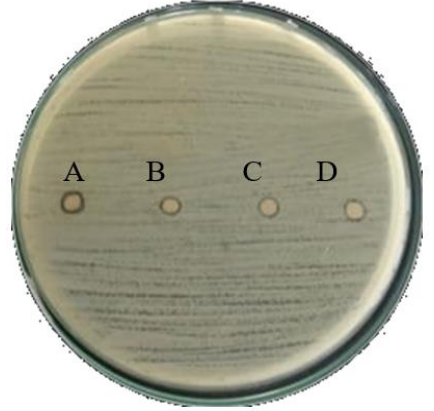

Escherichia coli

Figure 5. Result of Combination of FICI Melastoma malabathricum leaf ethanol extract with amoxicillin. Note: (A) $=$ combination of 2 times MIC amoxicillin and 2 times MIC extract, (B) = Combination 1 time MIC amoxicillin and 1 time MIC extract, (C) = Combination $1 / 2$ kali MIC amoxicillin and $1 / 2$ time MIC extract, (D) = Combination 1/4 kali MIC amoxicillin and 1/4 time MIC extract

Flavonoid is a derivative of phenol compound which is a protein coagulator. The mechanism of flavonoid compounds is to inhibit the function of the cell membrane by forming complexes with bacterial extracellular proteins through hydrogen bonds, causing the structure of cell walls and bacterial cell membranes to become unstable and resulting in the release of intracellular compounds (Ngajow 2013).

Flavonoid compounds can also inhibit energy metabolism by inhibiting the use of oxygen by bacteria; inhibition of $\mathrm{C}$ reductase occurs to inhibit the formation of metabolism (Bontjura 2015). The mechanism of flavonoids as antibacterials is to impede energy metabolism, while the phenol mechanism is to denature proteins, and the tannin mechanism is to form bonds with proteins resulting in protoplasmic coagulation in bacteria (Cushnie and Lamb 2005; Miyazawa et al. 2006). With the antibacterial properties of the compounds contained in the test material, it is suspected that the combination between the test plant and antibiotics is synergistic.

Phenol is a disinfectant compound that can be antibacterial by denaturation cell protein. The hydrogen bonds between phenol and protein cause the protein structure to become damaged. The hydrogen bond will affect the cell wall's and cytoplasmic membrane's permeability because both are proteins. The imbalance of macromolecules and ions in cells will cause cells to become lysis (Noventi 2016). Terpenoid mechanism as an antibacterial is by lysis of the bacteria cell wall. Terpenoid compound reacts to porin (transmembrane protein) in bacteria cell walls outside the membrane, forming strong polymer-bound, which destroys porin. Damage to the porin, the entry and exit point for the compound, will reduce the bacterial cell wall, which will cause the bacterial cell to lack nutrition so that the bacterial growth is stunted or dies (Astiani 2014).

In conclusion, this study, antioxidant activity $\mathrm{IC}_{50}$ value is $5.28 \mu \mathrm{g} / \mathrm{mL}$, total phenols $36.645 \pm 5.14 \%$, total flavonoids $4.163 \pm 0.2 \%$; and MIC values obtained at a concentration of $6.25 \mathrm{mg} / \mathrm{mL}$ against $B$. cereus with a diameter of $8.28 \mathrm{~mm} \pm 0.225$, against $B$. subtilis with a diameter of $8.53 \mathrm{~mm} \pm 0.275$, against $S$. aureus with a diameter of $7.23 \mathrm{~mm} \pm 0.275$, against $S$. epidermidis with a diameter of $6.18 \mathrm{~mm} \pm 0.104$; MIC values obtained at a concentration of $1.56 \mathrm{mg} / \mathrm{mL}$ in $E$. coli with a diameter of inhibition zone $6.77 \pm 0.72 \mathrm{~mm}, P$. mirabilis with a diameter of inhibition zone $6.32 \pm 0.19 \mathrm{~mm}$, and $P$. aeruginosa with a diameter of inhibition zone $6.40 \pm 0.26$ $\mathrm{mm}$. Therefore, the characteristics of the combination of $M$. malabathricum leaf ethanol extract and Amoxicillin towards $S$. epidermidis and B. subtilis with FICI value is one categories additive; $P$. aeruginosa with FICI value is two categories indifferent; E. coli, B. cereus, S. aureus and $P$. mirabilis with FICI value is 0.5 categories synergistic.

\section{ACKNOWLEDGEMENTS}

The authors thank the Indonesia Ministry of Health through the RISTOJA Grant 2016 and the Faculty of Medicine, University of Tanjungpura, Pontianak, Indonesia, through the DIPA Grant 2018. The authors 
declared that there is no conflict of interest during research activity and publication

\section{REFERENCES}

Alsherees HAA, Ali JA, Rana T. 2016. Molecular study of Proteus mirabilis bacteria isolated from urine and wounds in Hospitals AlNajaf Province. Intl J Adv Res Biol Sci 3 (6): 99-105.

Alwash MS, Nazlina I, Wan YA. 2013. Identification and mode of action of antibacterial components from Melastoma malabathricum Linn leaves. Am J Infect Dis 9 (2): 46-58. DOI: 10.3844/ajidsp.2013.46.58.

Andriyawan F. 2015. Uji Aktivitas Antibakteri Extract Etanol Daun Cengkodok (Melastoma malabathricum L.) Terhadap Escherichia coli secara in Vitro. [Hon. Thesis]. Fakultas Kedokteran Universitas Tanjungpura, Pontianak. [Indoensian]

Astiani DP, Afghani J, Savante A. 2014. Uji aktivitas antibakteri minyak atsiri Eucalyptus pellita terhadap bakteri Escherichia coli dan Staphylococcus aureus. J Kimia Khatulistiwa 3 (3): 49-53.

Bontjura S, Olivia AW, Krista VS. 2015. Uji efek antibakteri extract daun leilem (Clerodendrum minahassae L.) terhadap bakteri Streptococcus mutans. Pharmacon Jurnal Ilmiah Farmasi UNSRAT 4 (4): 2302 2493. [Indonesian]

Cushnie TPT, Lamb AJ. 2005. Antimicrobial activity of flavonoids. Intl J Antimicrob Agents. 26: 343-356. DOI: 10.1016/j.ijantimicag.2005.09.002.

Ministry of Health Republic of Indonesia. 2014. Survei Demografi dan Kesehatan Indonesia. Ministry of Health Republic of Indonesia, Jakarta. [Indonesian]

Miyazawa M, Utsunomiya H, Inada KI, Yamada T, Okuno Y, Tanaka H, Tatematsu M. 2006. Inhibition of Helicobacter pylori motility by (+) syringaresinol from unripe Japanese apricot. Biol Pharm Bull 29 (1): 172-173. DOI: 10.1248/bpb.29.172.

Faravani M. 2009. The Population Biology of Straits Rhododendron (Melastoma malabathricumL.) [Thesis] University of Malaya, Kuala Lumpur. Malaysia.

Hanani E. 2014. Analisis Fitokimia. Penerbit Buku Kedokteran EGC, Jakarta. [Indonesian]

Haryati NA, Chairul S, Erwin. 2015. Uji Toksisitas dan aktivitas antibakteri extract daun merah tanaman pucuk merah (Syzygium myrtifolium Walp.) terhadap bakteri Staphylococcus aureus dan Escherichia coli. Jurnal Kimia Mulawarman 13 (1): 35-40. [Indonesian]

Hiep TN. 2008. Smith's General Urology: Bacterial Infection of The Genitourinary Tract. $7^{\text {th }}$ ed. MC Graw Hill, New York.

Hossan S, Abu H, Bipasha A, Shahnawaz S, Masud K, Rownak J, Mohammed R. 2010. Traditional use of medicinal plants in Bangladesh to treat urinary tract infections and sexually transmitted diseases. Ethnobot Res Appl 8: 61-74.
ICMR. 2009. Detection of antimicrobial resistance in common Gramnegative and Gram-positive bacteria encountered in infections diseases- an update. ICMR Bull 39 (1-3): 1-20.

Kaur SP, Rao R, Nanda S. 2011. Amoxicillin: a broad-spectrum antibiotic. Intl J Pharm Sci 3 (3): 30-37.

Meutia C. 2017. Studi Etnofarmakologi, Toksisitas Akut dan Analgesik Extract Etanol Daun Cengkodok (Melastoma malabathricum L.) Tanaman Endemik Kalimantan Barat. [Hon. Thesis]. Fakultas Kedokteran Universitas Tanjungpura, Pontianak. [Indonesian]

Maulida M. 2016. Pola Resistensi Bakteri terhadap Antibiotik pada Penderita Sepsis Bayi di Ruang PICU dan NICU Rumah Sakit X Periode Agustus 2013 - Agustus 2015. Universitas Muhammadiyah Surakarta, Sukoharjo. [Indonesian]

Ngajow M, Jemmy A, Vanda S.K. 2013. Pengaruh antibakteri extract kulit batang matoa (Pometia pinnata) terhadap bakteri Staphylococcus aureus secara in vitro. Jurnal MIPA UNSRAT Online 2 (2): 128-132. [Indonesian]

Noventi W, Carolia N. 2016. Potensi extract daun sirih hijau (Piper betle L.) sebagai alternatif terapi Acne vulgaris. Majority 5 (1): 140-145. [Indonesian]

Nurmala, Virgiandhy I, Andriani, Liana D. 2015. Resistensi dan sensitivitas bakteri terhadap antibiotik di RSU dr. Soedarso Pontianak Tahun 2011-2013. eJKI 3 (1): 21-28. DOI: 10.23886/ejki.3.4803. [Indonesian]

Omar SNC, Abdullah JO, Khairoji KA, Chin SC, Hamid M. 2012. Potentials of Melastoma malabathricum Linn. flower and fruit extracts as antimicrobial infusions. Am J Plant Sci 3: 1127-1134. DOI: $10.4236 /$ ajps.2012.38136.

Pelczar MJ, Chan ECS. 2008. Dasar-dasar Mikrobiologi. Universitas Indonesia Press, Depok. [Indonesian]

Purwanto S. 2015. Uji Aktivitas antibakteri fraksi aktif extract daun senggani (Melastoma malabathricum L.) terhadap Escherichia coli. Jurnal Keperawatan Sriwijaya 2 (2): 84-92. [Indonesian]

Putri AVAA, Noor H, Vera, M. 2017. Pengaruh daya antibakteri extract daun stevia (Stevia rebaudiana Bertoni) pada concentration 5\%, 10\% $20 \%, 40 \%$ dan $80 \%$ terhadap Streptococcus mutans (In Vitro). Jurnal Ilmu Kedokteran Gigi 1 (1): 9-14. [Indonesian]

Radji M. 2010. Buku ajar mikrobiologi: panduan mahasiswa farmasi dan kedokteran. Penerbit Buku Kedokteran EGC, Jakarta. [Indonesian]

Smeltzer SC, Bare BG. 2008. Textbook of Medical-surgical Nursing. 8th ed. Lippincott Williams \& Wilkins, Philadelphia.

Susanti D, Sirat HM, Ahmad F, Ali RM. 2009. Bioactive constituents from the leaves of Melastoma malabathricum L. Jurnal Ilmiah Farmasi 5: 1-8

Tinrat S. 2015. Antimicrobial activities and synergistic effect of the combination of some edible mushroom extract with antibiotics against pathogenic strains. Intl J Pharm 35 (2): 253-262

Zimbro MJ, Power DA. 2009. Difco \& BBL Manual of Microbiological Culture Media Second Edition. Becton, Dickinson, and Company, United States of America. 